\title{
FRAKSINASI EKSTRAK METANOL KULIT BATANG Rhizophora mucronata DAN UJI DAYA HAMBATNYA TERHADAP BAKTERI Escherichia coli
}

\author{
Dian Riana Ningsih, Warsinah, dan Suwandri \\ Jurusan Kimia, Program Sarjana MIPA Unsoed Purwokerto
}

\begin{abstract}
Rhizhophora mucronata is commonly found mangrove plant due to it's wide distribution. The bark of this plant used for traditional medicine as slimming, antidiarrhea, anticonstipation. The chemical compounds of $R$. mucronata are tannins, alcaloide, flavanoids and saponin. In order to find out the effect of chemical activity of this plant, a research entitled Fractionation Metanol Extracts Bark of $R$. Mucronata and Inhibiting Capacity Assay against Escherichia coli Bacteria has been carried out.

The bark of $R$. mucronata was extracted by soxhlet with methanol solvent. Than methanol extract was fractionated with developing solvent kloroform : metanol (1:9) and producing five fractions that gave positive result on test for alcaloide compounds. The result of infrared spectroscopy that fraction 1-5 also contains of alcaloide. All fractions from coulomn chromatography tested on $E$. coli with dilution method which gave result that these fractions inhibit the growth of E. coli.
\end{abstract}

Key words : R. mucronata, fraction, E. coli

\section{PENDAHULUAN}

Indonesia kaya akan sumber daya alam khususnya sumber daya hayati seperti hutan tropis yang meliputi berbagai jenis tumbuhan. Dari 40.000 jenis tumbuhan yang tumbuh di Indonesia, hampir 1.000 jenis diantaranya dapat digunakan sebagai bahan obat tradisional. Salah satu jenis tumbuhan yang dapat digunakan sebagai bahan obat tradisional adalah tumbuhan mangrove. Tumbuhan mangrove merupakan sumber utama bahan kimia senyawa golongan tanin, saponin, terpenoid, steroid, dan alkaloid dengan berbagai aktivitas antara lain anti mikroba, anti fungi, anti virus, anti tumor dan anti leukimia (Soetarno, 1997).

$R$. mucronata adalah tumbuhan mangrove yang kulit batangnya banyak digunakan untuk obat tradisional diantaranya sebagai obat pelangsing, anti diare dan anti muntah (Departemen Kehutanan, 1997). Penelitian yang dilakukan Warsinah et al., (2002), menyimpulkan bahwa ekstrak kasar metanol kulit batang $R$. mucronata mengandung senyawa golongan alkaloid yang terdeteksi dengan pereaksi Dragendrof. Ekstrak kasar metanol kulit batang ini diperkirakan mengandung golongan senyawa tertentu yang dapat menghambat pertumbuhan bakteri Escherichia coli.

E. coli merupakan bakteri koliform yang bersifat patogen. Kehadiran bakteri tersebut di dalam contoh air menunjukkan adanya pencemaran yang berasal dari kotoran manusia atau hewan. Infeksi $E$. coli dapat mengakibatkan terjadinya diare, sebab bakteri tersebut mempunyai kemampuan untuk menghasilkan eksotoksin.

E. coli sebagai penyebab diare perlu dihambat pertumbuhannya. Langkah-langkah yang telah dilakukan untuk menghambat pertumbuhan E. coli yaitu dengan menggunakan obat sintetik, misal sulfonamid, ampicillin, chloraphenicol, tetracyclin dan polymixin 
(Karsinah, 1994). Penggunaan obat tersebut dapat menimbulkan sifat resistensi dari $E$. coli, sehingga untuk mengatasi masalah tersebut perlu dicari cara lain yang lebih aman.

Cara lain yang dapat digunakan untuk menghambat pertumbuhan $E$. coli yaitu dengan menggunakan bahan alami. Hal ini karena lebih aman penggunaanya dibandingkan dengan obat-obatan sintetik. Salah satu bahan alami yang digunakan adalah $R$. mucronata. Menurut Soetarno (1997), $R$. mucronata mengandung senyawa-senyawa kimia yang mempunyai sifat anti bakteri.

Fraksinasi dan isolasi lebih lanjut terhadap senyawa dalam ekstrak kasar metanol tersebut dilakukan untuk memperoleh senyawa polar yang lebih murni sehingga dapat memperjelas pengaruhnya pada uji bioessay yang dilakukan. Fraksinasi ekstrak kasar metanol kulit batang $R$. mucronata menggunakan kromatografi kolom, yang merupakan suatu metode pemisahan terbaik untuk memisahkan campuran dalam jumLah banyak (Sastrohamidjojo, 1985).

\section{METODE PENELITIAN Bahan}

Tanaman bakau ( $R$ mucronata), petroleum eter, etil asetat, metanol, khloroform, n-heksan, silika gel, alumina, kertas saring, pereaksi Dragendorf, glasswool, medium nutrien $\mathrm{NA}, \mathrm{HCl} 0,1$, $\mathrm{NaOH}$, medium NB.

\section{Peralatan}

Alat-alat gelas, soxhlet, timbangan, alat kromatografi lapis tipis, chamber, tabung kolom, lampu UV panjang gelombang $254 \mathrm{~nm}$ dan $366 \mathrm{~nm}$, evaporator, cawan petri, Drugalsky, lampu bunsen, autoklaf.

\section{Tahapan Penelitian}

Penelitian ini dilakukan dengan empat tahap :

1. Penyediaan sampel dan ekstraksi dengan metode soxhletasi
2. Penentuan eluen menggunakan Kromatografi Lapis Tipis

3. Fraksinasi menggunakan kromatografi kolom dan pengelompokan fraksi

4. Uji bioessay

Kulit batang $R$. mucronata dikeringkan dan dibuat serbuk. Masingmasing diekstraksi dengan pelarut petroleum eter, etil asetat, dan metanol dengan alat soxhlet berturut-turut secara terpisah selama 7 jam. Penentuan eluen yang digunakan dalam kromatografi kolom dilakukan dengan cara kromatografi lapis tipis terhadap ekstrak metanol. Eluen yang memberikan pemisahan terbaik yang digunakan untuk fraksinasi dengan kromatografi kolom. Hasil pemisahan dengan kromatografi kolom diuji secara kualitatif dengan perekasi Dragendorf dan diidentifikasi dengan spektroskopi IR. Masing-masing fraksi diuji daya hambatnya terhadap bakteri E. coli dengan metode dilusi.

\section{HASIL DAN PEMBAHASAN Ekstraksi Kulit Batang R. mucronata}

Ekstraksi kulit batang $R$. mucronata dilakukan secara berurutan dengan menggunakan pelarut petroleum eter, etil asetat dan metanol. Ekstraksi dengan pelarut metanol menghasilkan ekstrak kasar sebanyak 4,981 gram dari 16,972 gram sampel. Berat ekstrak kasar metanol yang diperoleh dari ekstraksi hanya $29,35 \%(b / b)$ dari berat sampel yang diekstraksi. Senyawa-senyawa yang terdapat dalam ekstrak metanol merupakan senyawa-senyawa polar karena metanol merupakan pelarut organik yang bersifat polar. Hal ini sesuai dengan pernyataan Dharmawan, et al., (1999) bahwa senyawa akan mudah larut dalam pelarut yang sama polaritasnya.

\section{Penetuan Eluen dengan Metode KLT}

Penentuan eluen yang digunakan dalam kromatografi kolom dilakukan dengan cara kromatografi lapis tipis terhadap ekstrak metanol. Eluen dapat 
berupa pelarut murni dan campuran dari dua atau lebih pelarut murni dengan perbandingan yang bervariasi. Campuran yang paling sederhana maksimal terdiri dari tiga komponen pelarut (Stahl, 1985). Ekstrak metanol dicoba dengan eluen yang berbeda-beda. Hasil KLT dari berbagai eluen yang diperoleh seperti pada tabel berikut :

Tabel 1. Hasil kromatografi lapis tipis ekstrak metanol kulit batang $R$. mucronata

\begin{tabular}{|c|c|c|c|c|}
\hline \multirow[t]{2}{*}{ Eluen } & \multicolumn{2}{|c|}{ Warna pada UV } & \multirow{2}{*}{$\begin{array}{l}\text { JumLa } \\
\text { h noda }\end{array}$} & \multirow[t]{2}{*}{ Ket } \\
\hline & $254 \mathrm{~nm}$ & $366 \mathrm{~nm}$ & & \\
\hline $\mathrm{A}$ & - & Gelap & - & $\begin{array}{l}\text { Tidak } \\
\text { terelusi }\end{array}$ \\
\hline B & - & Gelap & - & $\begin{array}{l}\text { Tidak } \\
\text { terelusi }\end{array}$ \\
\hline $\mathrm{C}$ & $\begin{array}{l}\text { Noda } \\
\text { coklat } \\
\text { Latar } \\
\text { belakang } \\
\text { kuning }\end{array}$ & Gelap & - & $\begin{array}{l}\text { Terelusi } \\
\text {,tidak } \\
\text { terpisah }\end{array}$ \\
\hline $\mathrm{D}$ & $\begin{array}{l}\text { Noda } \\
\text { coklat } \\
\text { Latar } \\
\text { belakang } \\
\text { kuning }\end{array}$ & Gelap & 1 & $\begin{array}{l}\text { Terelusi } \\
\text { terpisah }\end{array}$ \\
\hline $\mathrm{E}$ & $\begin{array}{l}\text { Noda } \\
\text { coklat } \\
\text { Latar } \\
\text { belakang } \\
\text { kuning }\end{array}$ & Gelap & - & $\begin{array}{l}\text { Terelusi } \\
\text { tidak } \\
\text { terpisah }\end{array}$ \\
\hline
\end{tabular}

Keterangan: A. kloroform : etanol $(9: 1)$

B. kloroform : metanol (1:9)

C. n Heksan : kloroform (9:1)

D. kloroform : metanol (3:7)

E. etil asetat : etanol $(9: 1)$

Dari Tabel 1 diketahui bahwa eluen kloroform : metanol (1:9) dapat memberikan pemisahan terbaik dengan satu spot. Sedangkan eluen yang lain tidak memberikan pemisahan yang baik. Hal ini mungkin disebabkan karena eluen-eluen tersebut memiliki polaritas yang lebih rendah dari ekstrak metanol atau mungkin juga karena perbandingan pelarut-pelarut penyusun eluen tersebut kurang tepat. Eluen yang memberikan pemisahan terbaik yaitu kloroform : metanol (1:9) ini, selanjutnya digunakan sebagai eluen dalam fraksinasi dengan kromatografi kolom.

\section{Fraksinasi dengan Kromatografi Kolom dan Uji Kualitatif dengan Pereaksi Dragendrof}

Eluen yang memberikan pemisahan terbaik yaitu kloroform : metanol (1:9) ini, selanjutnya digunakan sebagai eluen dalam fraksinasi dengan kromatografi kolom. Teknik kromatografi kolom menggunakan kolom kaca yang diisi dengan adsorben dan kepadatannya diseragamkan. Perbandingan sampel ekstrak dengan alumina yang dimasukkan dalam kolom adalah $1: 30$. Kolom dielusi dengan eluen kloroform : metanol (1:9). Fraksi yang diperoleh ditampung dalam vlakon, tiap-tiap vlakon berisi $2 \mathrm{~mL}$ eluat. Fraksi-fraksi dengan penampakan visual yang sama digabung menjadi satu sehingga diperoleh lima fraksi. Pengelompokan fraksi selanjutnya dilakukan dengan menggunakan pereaksi warna Dragendrof . Pereaksi tersebut digunakan untuk dasar pengelompokan fraksi secara uji kualitatif yang menunjukkan adanya golongan senyawa tertentu. Hasil pengelompokan fraksi hasil kromatografi kolom dan uji kualitatif ditampilkan dalam tabel berikut ini:

Hasil uji pada Tabel 2 menunjukkan bahwa kelima fraksi tersebut positif mengandung senyawa golongan alkaloid karena menghasilkan warna orange. Hal ini sesuai dengan pernyataan Cannel (1998) bahwa hasil positif adanya alkaloid menggunakan pereaksi Dragendrof ditunjukkan dengan munculnya warna orange. Pereaksi Dragendrof mengandung $\mathrm{K}\left(\mathrm{BiI}_{4}\right)$ yang umumnya dengan basa $\mathrm{N}$ pada alkaloid memunculkan warna orange. 
Tabel 2. Hasil fraksinasi ekstrak metanol kulit batang $R$. mucronata serta uji kualitatif alkaloid dengan pereaksi Dragendrof

\begin{tabular}{|c|c|c|c|c|}
\hline \multirow{2}{*}{ Fraksi } & \multirow{2}{*}{ Rf x 100 } & \multicolumn{2}{|c|}{ Sinar UV (nm) } & \multirow{2}{*}{ Dragendroff } \\
\cline { 3 - 4 } & & 254 & 366 & \\
\hline F1 & 70 & Noda coklat & Gelap & Orange \\
\hline F2 & 75 & Noda coklat & Gelap & Orange \\
\hline F3 & 78 & Noda coklat & Gelap & Orange \\
\hline F4 & 81 & Noda coklat & Gelap & Orange \\
\hline F5 & 84 & Noda coklat & Gelap & Orange \\
\hline
\end{tabular}

Identifikasi dengan Spektroskopi Infra Merah (IR)

Fraksi-fraksi yang diperoleh kemudian diidentifikasi dengan spektroskopi IR untuk mengetahui gugusgugus apa yang terdapat pada fraksi- fraksi tersebut. Hasil analisis spektra IR fraksi 1, 2, 3, 4 dan 5 dengan metode pelet $\mathrm{KBr}$, menunjukkan adanya beberapa gugus. Lebih jelasnya hasil spektra IR dapat dilihat pada Tabel 3 .

Tabel 3. Absorpsi infra merah gugus-gugus fungsi pada fraksi 1-5

\begin{tabular}{|c|c|c|c|c|}
\hline Fraksi & $\begin{array}{l}\text { Bilangan Gelombang } \\
\left(\mathrm{cm}^{-1}\right)\end{array}$ & $\begin{array}{l}\text { Literatur (Silverstain } \\
\text { et al., 1986) }\end{array}$ & Intensitas & Gugus \\
\hline \multirow{5}{*}{$\mathrm{F} 1$} & 3441 & $3200-3500$ & lebar & O-H (regangan) \\
\hline & $2923-2848$ & $3000-2800$ & tajam & C-H (regangan) \\
\hline & $1648-1560$ & $1560-1640$ & tajam & N-H (tekuk) \\
\hline & 1407 & $1400-1500$ & sedang & C-H (tekuk) \\
\hline & $1119-1055$ & $1020-1250$ & lemah & C-N,C-O,C-C (regangan) \\
\hline \multirow{5}{*}{$\mathrm{F} 2$} & 3417 & $3200-3500$ & lebar & O-H (regangan) \\
\hline & $2925-2848$ & $3000-2800$ & tajam & C-H (regangan) \\
\hline & $1637-1560$ & $1560-1640$ & sedang & N-H (tekuk) \\
\hline & 1401 & $1400-1500$ & sedang & C-H (tekuk) \\
\hline & 1108 & $1020-1250$ & sedang & C-N,C-O,C-C (regangan) \\
\hline \multirow{5}{*}{ F3 } & 3439 & $3200-3500$ & lebar & O-H (regangan) \\
\hline & $2919-2848$ & $3000-2800$ & sedang & C-H (regangan) \\
\hline & $1637-1560$ & $1560-1640$ & tajam & N-H (tekuk) \\
\hline & 1407 & $1400-1500$ & tajam & C-H (tekuk) \\
\hline & $1119-1043$ & $1020-1250$ & lemah & C-N,C-O,C-C (regangan) \\
\hline \multirow{2}{*}{ F4 } & 3445 & $3200-3500$ & lebar & O-H (regangan) \\
\hline & $2922-2848$ & $3000-2800$ & tajam & C-H (regangan) \\
\hline
\end{tabular}




\begin{tabular}{|l|c|l|l|l|}
\hline \multirow{4}{*}{} & 1560 & $1560-1640$ & sedang & N-H (tekuk) \\
\cline { 2 - 5 } & 1401 & $1400-1500$ & sedang & C-H (tekuk) \\
\cline { 2 - 5 } & 1037 & $1020-1250$ & lemah & C-N,C-O,C-C (regangan) \\
\cline { 2 - 6 } F5 & 3426 & $3200-3500$ & lebar & O-H (regangan) \\
\cline { 2 - 5 } & $2922-2848$ & $3000-2800$ & tajam & C-H (regangan) \\
\cline { 2 - 6 } & $1637-1560$ & $1560-1640$ & sedang & N-H (tekuk) \\
\cline { 2 - 6 } & 1401 & $1400-1500$ & tajam & C-H (tekuk) \\
\hline
\end{tabular}

Dari Tabel 3 diketahui bahwa fraksi 1, 2, 3, 4 dan 5 mengandung gugus-gugus yang sama hanya berbeda bilangan gelombang dan intensitasnya, hal ini menunjukkan bahwa fraksi-fraksi tersebut merupakan senyawa yang berbeda tetapi memiliki gugus-gugus yang sama. Berdasarkan gugus-gugus yang ditunjukkan spektra IR bahwa fraksi 1-5 mengandung senyawa golongan alkaloid.

Uji Daya Hambat Fraksi Ekstrak Metanol Kulit Batang $R$. mucronata terhadap Bakteri $E$. coli

Masing-masing fraksi kemudian diujikan terhadap bakteri E. coli, adapun hasil penghambatan fraksi ekstrak metanol $R$. mucronata terhadap pertumbuhan bakteri $E$. coli dapat dilihat pada tabel berikut :

Tabel 4. Uji daya hambat masing-masing fraksi

\begin{tabular}{|l|l|l|l|}
\hline \multirow{2}{*}{ Fraksi } & \multicolumn{2}{|l|}{ JumLah koloni $\left(10^{-7}\right)$} & \multirow{2}{*}{ Rata-rata } \\
\cline { 2 - 3 } & \multicolumn{2}{|l|}{ Ulangan } \\
\cline { 2 - 3 } & 1 & 2 & \\
\hline F1 & 29 & 18 & 23 \\
\hline F2 & 41 & 36 & 38 \\
\hline F3 & 101 & 71 & 86 \\
\hline F4 & 30 & 4 & 17 \\
\hline F5 & 48 & 75 & 61 \\
\hline Kontrol & 256 & 211 & 233 \\
\hline
\end{tabular}

Dari tabel di atas menunjukkan bahwa masing-masing fraksi memberikan penghambatan terhadap pertumbuhan bakteri E. coli. Hal ini ditunjukkan dengan jumLah koloni dari bakteri $E$. coli yang cenderung turun setelah diberi perlakuan fraksi ekstrak metanol kulit batang $R$. mucronata. Mekanisme penghambatan terhadap bakteri $E$. coli di duga disebabkan oleh aktivitas alkaloid. Efek anti bakteri senyawa golongan alkaloid dimungkinkan mempunyai kesamaan dengan senyawa obat sulfonamida yaitu menghambat sintesis asam folat. Hal ini didasarkan pada kesamaan kerangka dasar yang dimiliki oleh alkaloid dengan sulfonamida yaitu kerangka polisiklik termasuk cincin heterosiklik nitrogen (Achmad, 1986).

Alkaloid maupun sulfonamida mempunyai analog struktural dengan PABA (asam p-aminobenzoat) sebagai zat yang digunakan untuk membentuk asam folat yang digunakan untuk sintesis purin dan asam-asam nukleat. Mikroba patogen dalam sintesis asam folat memerlukan PABA yaitu suatu vitamin B untuk melengkapi pembentukan asam folat dan vitamin ini sangat penting untuk pertumbuhannya (Setiabudy \& Gan, 1995). Ketika alkaloid masuk ke dalam sel bakteri maka akan berkompetisi dengan PABA dalam menempati sisi aktif enzim yang berperan dalam sintesis asam folat yaitu hidropteroat sintetase (Prescott et al., 1999). Kombinasi tersebut mencegah sintesis asam folat. 
Hal ini sangat merugikan bakteri karena dapat menghambat sintesis purin dan asam-asam nukleat, akibatnya bakteri tidak dapat bereplikasi dan akhirnya mengarah pada kematian sel.

\section{KESIMPULAN}

Hasil Penelitian ini dapat disimpulkan :

1. Fraksinasi ekstrak kasar metanol kulit batang $R$. mucronata dihasilkan fraksi-fraksi yang mengandung senyawa golongan alkaloid.

2. Fraksi 1, 2, 3, 4 dan 5 mampu menghambat pertumbuhan bakteri $E$. coli.

\section{DAFTAR PUSTAKA}

Achmad, 1986, Kimia Organik Bahan Alam, Penerbit Karunka, Jakarta.

Cannel, R. J. R., 1998, Natural Product Isolation, Human Press, New Jersey.

Dharmawan, N., Purnama Darmaji, Eni Harmayani, 1999, Kemampuan Ekstrak Fraksi-Fraksi Buah Pace (Morinda citrifolia) sebagai Antibakteri, Prosiding Seminar Nasional Pangan, Pusat Antar Universitas Pangan dan Gizi UGM, Yogyakarta.

Departemen Kehutanan, 1997, Strategi Nasional Pengelolaan Mangrove di Indonesia, Jilid 1.

Karsinah, 1994, Bakteri Gram Negatif. Dalam Dr. H. Sujudi (penyunting), Mikrobiologi Kedokteran, Bina Rupa Aksara, Jakarta.

Prescott, L. M., Harley, J. P., Klein, D. A., $1999, \quad$ Microbiology, $4^{\text {th }}$ Edition, McGraw Hill Company, Inc, USA.
Sastrohamidjojo,H., 1985, Kromatografi, Liberty, Yogyakarta.

Setiabudy. R. \& V. H. S. Gan., 1995, Farmakologi dan Terapi Antimikroba, Basian Farmakologi Fakultas Kedokteran UI, Jakarta.

Soetarno, S., 1997, Potensi dan Manfaat Tumbuhan Mangrove sebagai Sumber Bahan Bioaktif, Acta Pharmaceutica Indonesia, Vol XXII.

Stahl, E., 1985, Analisa Obat secara Kromatografi dan Mikroskopi, ITB, Bandung.

Warsinah, S. N., Nurhandayani, S. S. Susilowati, 2002, Penjaringan dan Isolasi Alkaloid pada Tumbuhan Bakau R. mucronata sebagai Obat Anti Inflamasi dan anti Demam, Laporan Proyek Due Batch II UNSOED, Purwokerto. 